\title{
Critical Analysis of Cooperative Learning in Chinese ELT Context
}

\author{
Weihong Li \\ Foreign Language Department, Beijing Information Science \& Technology University, Beijing, China \\ Email: bellevive@yahoo.com.cn
}

\begin{abstract}
The study aims to explore the application of Cooperative Learning in Chinese ELT context through interview, questionnaire, date analysis and discussion. Classrooms Cooperative Learning facilitates a supportive learning environment for English language learners. Cooperative Learning is a creative and effective teaching strategy in European and American countries. It can play a positive role on increasing harmony in classrooms, learners' academic achievement, self-esteem, greater liking for the subject matter and social ability. Whether it can be applied appropriately in Chinese ELT Teaching context or not depends on many factors.
\end{abstract}

Index Terms - cooperative learning, Chinese ELT context, influence of other factors

\section{INTRODUCTION}

According to Cook (2001), successful teaching results from learning; if students do not learn from the teaching, there is no benefit no matter how entertaining, lively, or well constructed the lessons are. What teaching methods the teacher employs in a specific class depends substantially on the practical realities of the classroom (Richards \& Rodgers, 2003). Language contexts in the world not only have a large variety of differentiation in their culture, society, education system, but also learners' value, attitude, motivation and learning habit, which affects the different applications of the same teaching model in different contexts. This paper investigates the practices of Cooperative Learning in Chinese ELT (English Language Teaching) context and the possible problems.

English, as a compulsory subject in middle schools and universities from the economic reform and opening of China in 1978 and 1979, has become essential learning process in China. This change produces many issues that Chinese ELT teachers have to think over, such as the debate on the subject of the appropriateness and effectiveness of importing "Western" ELT methods, including Cooperative Learning method, to the English teaching in the People's Republic of China. In this debate, some scholars insist on that the Chinese traditional ways of teaching and learning is very important in Chinese ELT context and have got great achievements for the improvement of English in China (Harvey, 1985; Sampson, 1984; Liu,1999; Fan, 2000;). Other authors and scholars have paid attention to the value of adopting Western teaching approaches in China (Li, 1984; Maley, 1984, 1986; Spencer, 1986). But most of them have focused on the need to adapt Western practices to the context for language learning and teaching in China with specific demands and conditions (Scovel, 1983). Cooperative Learning method, as a creative and effective teaching strategy in European and American countries, is among the arguments. Therefore, this research puts focus on the process of application of Cooperative Learning in Chinese teaching context, the relevant problems and how to apply the method appropriately and effectively into Chinese ELT context.

\section{LITERATURE REVIEW}

\section{A. What Is Cooperative Learning?}

Cooperative Learning is not only a learning method but also a kind of teaching strategy. It has a 300 years history. In 1700, it origins in Britain. In 1806, it was sent to America. In 1970s to 1990s, it became very popular in modern Cooperative Learning research. At the end of 1990s, it leads to broad discussion in the Chinese education field. Cooperative Learning is defined as a set of instructional strategies by which small groups of students to facilitate peer interaction and cooperation for studying academic subjects (Sharan, 1980). It is a kind of learning style by working together for a common goal and caring about each other's leaning (Sharan, 1980; Johnson \& Johnson, 1999). According to Slavin (1980, p.315), "the term refers to classroom techniques in which students work on learning activities in small groups and receive rewards or recognition based on their group's performance". Cooper and Mueck (1990) regard Cooperative Learning as a structured and systematic instructional design in which small groups work together to reach a common goal. Therefore, Cooperative Learning obviously would put students together in groups and give them tasks to do. During this process, the necessary learning environment or learning context has to be guaranteed. According to Johnson and Johnson model of Cooperative Learning, the context includes the following five elements: Positive Interdependence creates the feeling that the group "sinks or swims together"; Face-to-Face Interaction requires each team to sit in close proximity, eye-to-eye and knee-to-knee; Individual Accountability means each person must know 
the material; Social Skills refers to each student must work at implementing the selected social skill and the instructor must monitor for its use; Processing provides the opportunity to reflect on how well they functioned as a team and what they can do next time to be even better. (Johnson, Johnson, \& Smith, 1998) Thus, Cooperative base groups of three to four students worked together during the whole course and could bestow each student the support, encouragement, and assistance needed to progress academically (Johnson, Johnson, and Smith 1991)

\section{B. The Advantages of Cooperative Learning}

Many scholars support the idea that Cooperative Learning can facilitate learners' cognitive growth. According to Piaget (1926), qualities of students' peer interactions that may contribute to students' learning within cooperative learning groups. His work stressed the benefits of cognitive conflicts among students that expose students' misconceptions and lead to higher-quality understandings. Bandura (1971) points out that cognitive learning, eventually, presents learners with a variety of opportunities to learn from each other and to achieve a higher cognition. Vygotskian (1978) theory focus on that learners' cognition is promoted when they are interacting with others in their environment and in cooperation with their peers. Thus, it is essential to build a relevant real and communicative context in which learners can make numerous opportunities of interactions with different people. In terms of Murray's(1994) notion, Cooperative Learning suggests that learning would be more meaningful if learners should participate in their own learning instead of listening to the teacher's lectures. Moreover, conflicts resolution will help promote students' cognitive growth.

As many researchers claim, learning context has its own achievement-relevant beliefs, goals and values and this system tends to influence learners' learning motivation to a great degree (Grant and Dweck, 2001). However, "in classroom contexts, in particular, it is rare to find dramatic motivational events that - like a lightening or a revelation reshape the students' mindsets from one moment to another." (Dornyei, 2005, p.25) To motivate learners, it is necessary to protect learners' self-confidence, respect their needs and interests (Nunan and Lamb, 1996). Cultivating a pleasant, relaxing classroom atmosphere is also necessary to motivate learners to learn well (Dornyei and Csizer, 1998). If learners could feel respected and connected with others, the self-esteem is strengthened when Cooperative Learning build a relaxing and comfortable classroom atmosphere (Cohen and Willis, 1985). In Cooperative Learning, anxiety is diminished and self-confidence is increased because the class attention is not focused on an individual but on a whole group and when a mistake is made, it becomes a learning process rather than a public criticism (Slavin and Kaweit, 1981). So Cooperative Learning makes learners feel comfortable to express their ideas in the target language without hesitation. Therefore, Cooperative Learning could enhance the learners' motivation.

Cooperative Learning Structures always include following factors (Kagan, 1990): class building, team building, communication builders, mastery, concept development, division of labor, cooperative projects. Certain common Cooperative Learning activities are: Think-Pair-Share (TPS), Numbered Heads together, jigsaw, circle the sage, etc. All these activities can create more opportunities of interaction. Research has shown that Cooperative Learning benefits ELT in various aspects such as constructive peer interaction and active learning (Ovando, Combs \& Collier, 2006).

\section{Methodology}

In this research the deductive approach is employed in the process of review of the Cooperative Learning. In analysis, inductive method and deductive methods are combined to describe Chinese ELT context and existing problems.

In order to increase the validity of the research, the date collection both in western academic world and Chinese academic world, data analysis, interviews, questionnaire, observing classes and discussions are used to cover different viewpoints. The research has chosen 119 students in a certain Beijing university and 20 ELT teachers from 14 Beijing colleges and universities to do the questionnaires and interviews (see Appendix I \& Appendix II). In terms of the same teaching institution, education system and facilities, this research also presents the analysis of the whole country's ELT in general. Despite many limitations and problems in application of Cooperative Learning in China, the research emphasizes the significance of the application of Cooperative Learning in Chinese ELT teaching context and the importance of the Cooperative Learning to learners' practical proficiency in English.

\section{COOPERATIVE LEARNING IN CHINESE ELT CONTEXT}

\section{A. Chinese ELT Learners in Cooperative Learning}

In the light of questionnaires to Chinese ELT learners, for $85.4 \%$ students, the main purpose to learn English is to pass the English examinations, which do not have the speaking assessment. $76.7 \%$ learners are used to the teaching style of teachers doing lectures and they learning from teachers. If they do group classroom activities among peers for a whole class period, many students will complain that they learn nothing from the class, because the teacher teaches little in the class. They do not believe they can learn from each other. Thus $88.6 \%$ learners prefer learning by themselves to cooperating by groups with their peers.

Learners, as the subjects of ELT, are also various in China. According to Laird (2005), learner diversity is an asset to be capitalized on to promote profound, meaningful learning. Sarasin (1999) acknowledges the values of learner diversity. He points out that language teachers improve their teaching because their teaching benefits from the diversity 
of their students. However, Johnson and Johnson (1999) discover Asian (in Vietnam, or China) classroom activity is still dominated by an individualistic structure, which puts the emphasis on individual learner to achieve the goal independently instead of cooperating with other learners, and in a competitive learning atmosphere, learners are pursuing individually "best" performance against others. In Chinese ELT classrooms, ELT teachers can transfer the traditional teaching methods into Cooperative Learning style, but they cannot change the way learners complete the classroom activity individually, even if they are doing the Cooperative Learning tasks. The learners who are used to competing with each other are always pursuing to be the best. They actually do not want to cooperate with others and prefer to perform individually. Therefore, the effect of Cooperative Learning is really hard to completely realize in Chinese ELT classrooms. For this point, teacher cannot change the internal value of learners which is built by the whole society.

\section{B. Chinese ELT Teachers in Cooperative Learning}

According to the questionnaires and interviews to Chinese ELT teachers, 55\% teachers acknowledge they are familiar with Cooperative Learning teaching style, $40 \%$ teachers say they know about it but not quite well, $5 \%$ teachers say they know nothing about it. $80 \%$ teachers have tried to use Cooperative Learning strategies in their classroom activities, but few of them think it has obvious efficiency for students' improvement. $75 \%$ teachers recognize that they still do lectures a lot to explain vocabulary, grammar, and sentence structure in the classroom teaching. The major roles of them still are teachers not guides of classroom activities. Most of the teachers argue about the factors of the big class size, limited teaching time, poor teaching space and facilities, which influence the Chinese teaching style a lot.

Many Chinese ELT teachers still cannot appropriately adapt to the Cooperative Learning style in their classrooms. In China, although Confucianism has not survived as an dominant contemporary philosophy, its values continue to exert impact on the daily lives (Bannai, 1980); especially in education, it continues to sustain a high teachers' portrait as the symbol of knowledge, wisdom, and behavior (Medgyes, 1986). Although the ELT requirements of the Ministry of Education of the People's Republic of China (2007) demands that changes in the teaching model by no means call for changes in teaching methods and approaches only, but, more important, consist of changes in teaching philosophy and practice, and in a shift from a teacher-centered pattern to a student-centered pattern, in which English teachers should be the facilitators of students and the stimulators of students, many Chinese ELT teachers still cannot give up the traditional teaching model, in which teaching and learning are still teacher-centered through a series of lectures. Even many ELT teachers in China still feel more comfortable to teach by Grammar-Translation methods.

In China, because of the long-term influence of traditional teaching style, many Chinese ELT teachers cannot apprehend the spirit of cooperative learning correctly. The teachers do wrongly in the process of the application, which lead to some problems in Chinese ELT classroom. More often than not, the teachers do not use the cooperative learning strategies to attain the language proficiency instead of pursuing a high mark in assessment. For example, in some Chinese so-called cooperative learning classroom activities, the students are divided into several groups to do their tasks with loud noise. Without clear requirements and necessary instructions, some active students learn a lot, but some shy or lower-level students cannot really indulge into the process of learning, while it takes a lot of time. Of course, these students cannot think deeply through the cooperative classroom activity. This phenomenon arises from the teachers' misunderstanding to the cooperative learning. They consider the cooperative learning as students' task and ignore the responsibility of designing and organizing of the classroom activities. Thus, while the students are doing the exercises, the teachers usually do not participate or provide guide to the classroom activity. Even some students speak Chinese to communicate or talk about something beyond the classroom activity task.

\section{Chinese ELT Environment to Cooperative Learning}

Many important teaching approaches have been incorporated into materials directly or indirectly (McDonough \& Shaw, 2003). At the same time, one of the important abilities for professional ELT teachers is to evaluate the effectiveness of the teaching materials (McDonough \& Shaw, 2003). Brown \& Yule (1994, p.80-88) believes that the aims of the course decide the selection of the teaching materials. He presents his own criteria of teaching materials selection for: "Grading materials: by speaker"; "Grading materials: by intended listener"; "Grading materials: by content"; "Grading materials: by support"; "Choosing materials: type of purpose". In Chinese ELT classroom, almost every program has its corresponding course book. Teachers have to finish the compulsive part of the content in the course book in specified term. While the teaching materials in the course book pay much attention to the vocabulary, grammar rules and sentence structures instead of actual life communication. Teachers have no right for selection of the teaching materials, which objectively confine the efficiency of the application of Cooperative Learning.

Concerning about classroom layout, Harmer (2006) concludes that the orderly rows are suitable for lectures and big size classes with 40 and 200 students at a time; while circles and horseshoes are more suitable for smaller classes to communicate between learners. In a circle or a horseshoe, the classroom becomes a more intimate and friendly place. Mckay and Tom (1999) said that the friendly and supportive atmosphere in a classroom makes learners willing to take risks in using the new language. Actually, in Chinese ELT environment, the class size normally is quite big, which could be 35 to 70 students, and even more. Sometimes, the desks in the classroom are fixed on the floor and cannot be moved. This kind of classroom layout makes the application of the Cooperative Learning more difficult. 


\section{SumMary OF THE RESEARCH}

Context and activity mutually influenced one another (Lave, 1988). To the current specific language teaching context in China, the application of Cooperative Learning is more appropriate in Speaking \& Listening class. The traditional teaching methods and lectures are still employed broadly in Reading \& Writing classes because of the confining elements mentioned above. Cooperative Learning will become more popular in Chinese ELT classroom activities with the enhancing of the comprehension and values of both teachers' and students' and the improvement of ELT environment in China. At that time, the advantages of Cooperative Learning can fully work its functions in Chinese ELT context. Perhaps, it is a long way to go. It needs the endeavor of many aspects, which include not only the efforts of teachers and learners, but also the co-effort of Chinese society, government relevant departments, administrator in different schools.

\section{APPENDIX I: QUESTIONNAIRE FOR STUDENTS}

\section{BACKGROUND INFORMATION}

Purpose of the study:

This questionnaire is being conducted for the study on Cooperative Learning in Chinese ELT context.

The goal of this questionnaire is to map the understanding and views of students on Cooperative Learning in classroom. This questionnaire will take 10 minutes to complete.
1. Sex: (please tick)
Female $\square$
Male $\square$
2. Age:
3. Major:
4. Spoken English Level

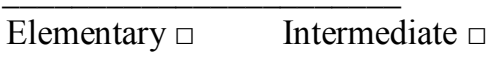
Advanced $\square$

\section{COOPERATIVE LEARNING QUESTIONS FOR STUDENTS}

1. What's your main purpose to learn English?
a. pass the relevant examination and get the certificate
b. improve English proficiency
c. learn how to read and write in English in academic study
d. go abroad to be immigrant

2. How many classmates are there in your English classroom?
a. about 20
b. about 30
c. about 40
d. over 50

3. When you learn English in classroom, would you like to work together with other students in group and aid each other or learn individually?
a. Learn in groups
b. Learn individually

4. When you learn English in classroom, who do you prefer to learn from?
a. from teacher only
b. from interaction between peers
c. from both teacher and peers
d. from neither teacher or peers, learn by yourself

5. Which English teaching style do you prefer?
a. lectures by teacher
b. classroom cooperative activities under the guide of teacher
c. classroom cooperative activities without the guide of teacher
d. other teaching style:

6. What does the examinations you have to take part in often include?(you can choose more than one)
a. Listening
b. Speaking
c. Reading
d. Writing
e. Translation

7. What's your classroom layout? Are the desks in the classroom fixed on the floor or not?
a. always orderly row/traditional row
b. always circles
c. always horseshoe
d. always change according to teachers' requirements for each class

8. Where could you easily find a place to do cooperative task with you group after class?
a. in library 
b. in classroom
c. in campus
d. in dormitory

APPENDIX II: QUESTIONNAIRE FOR TEACHERS

\section{BACKGROUND INFORMATION}

Purpose of the study:

This questionnaire is being conducted for the study on Cooperative Learning in Chinese ELT context.

The goal of this questionnaire is to map the understanding and views of ELT teachers on Cooperative Learning in classroom. This questionnaire will take 10 minutes to complete.

1. Sex: (please tick) $\quad$ Female $\square \quad$ Male $\square$

2. Age:

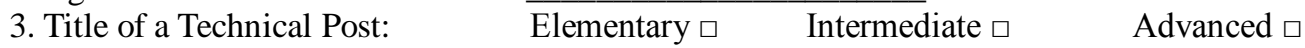

\section{COOPERATIVE LEARNING QUESTIONS FOR TEACHERS}

1. Are you familiar with the Cooperative Learning?

a. Yes, quite well

b. No, know nothing about it

c. Yes, but not quite well

2. Do you apply Cooperative Learning strategies in your classroom teaching?
a. Yes, quite a lot
b. Yes, sometimes
c. No, not at all

3. What's kind of teaching style you often use and feel more comfortable?
a. Grammar-translation
b. cooperative learning
c. other style:

4. What's teaching mode you always use in classroom teaching?
a. mainly lectures
b. mainly classroom activity
c. both lectures and classroom activity
d. other mode:

5. What's you role, do you think, in the class?
a. a teacher who can teach new knowledge to students and explain the problem which students do not know
b. a guide, organizer, or facilitator for students to get English proficiency
c. both

6. How many students are there in your English class?
a. about 20
b. about 30
c. about 40
d. over 50

7. For the current teaching materials, which teaching method do you think is more suitable for it?
a. traditional teaching method
b. cooperative learning classroom activity
c. others:

8. Do you think the current classroom layout is proper to do cooperative learning activity in class?

a. Yes, it is possible.

b. No, it is too small and the desks could not be moved.

9. Which teaching style do you think is more time-consuming?
a. traditional teaching method
b. cooperative learning activity

10. Which teaching style do you think is more effective in the improvement of students' reading and writing?

a. traditional teaching method

b. cooperative learning activity

11. Which teaching style do you think is more effective in the improvement of students' speaking and listening?

a. traditional teaching method

b. cooperative learning activity

\section{REFERENCES}

[1] Bandura, A. (1971). Social Learning Theory. NJ: Prentice Hall Regents. 
[2] Bannai, H. (1980). Socio-cultural influences on the communication development of Asian ESL students. In Fisher, J.C., Clarke, M.A., \& Schachter, J. (Eds.), Building bridges: Research and practice in teaching English as a second language (pp. 147-158). Washington, D.C.: TESOL.

[3] Brown, G. \& Yule, G. (1994). Teaching the Spoken Language. $11^{\text {th }}$ ed. Cambridge: Cambridge University Press.

[4] Cohen, S. \& Willis, T. (1985). Stress and Social Support and the Buffering Hypothesis. Psychological Bulletin, 98, 310-357.

[5] Cook, V. (2001). Second Language Learning and Language Teaching (3rd ed.). Oxford: Oxford University Press.

[6] Cooper, J \& Mueck, R. (1990). Student Involvement in Learning: Cooperative Learning and College Instruction. Journal on Excellence in College Teaching, 1, 68-76.

[7] Dornyei, Z. \& Csizer, K. (1998). Ten Commandments for Motivating Language Learners: Results of an Empirical Study. Language Teaching Research, 2: 203-229.

[8] Dornyei, Z. (2005), Motivational Strategies in the Language Classroom, United Kingdom, the Cambridge University Press.

[9] Fan, W., (2000). Correct views on the traditional method of foreign language teaching. XiAn: Foreign Language Education. (2), 46-48.

[10] Grant, H and Dweck, CS (2001) Cross-cultural response to failure: considering outcome attributions with different goals. In Salili, F, Ghiu, G and Hong, Y (eds) Student motivation: The Culture and context of learning, Kluwer Academic/Plenumm Publishers, New York, pp. 203-219.

[11] Harmer, J. (2006). How to Teach English. England: Addison Wesley Longman Limited.

[12] Harvey, P. (1985). A lesson to be learned: Chinese approaches to language learning. English Language Teaching Journal, 39 , 183-186.

[13] Johnson, D.W., Johnson, R.T. (1999). Learning together and alone: Cooperative, competitive, and individualistic learning (5 ${ }^{\text {th }}$ ed.). Boston: Allyn and Bacon.

[14] Johnson, D.W., R. T. Johnson, and K. A. Smith. (1991). Cooperative learning: Increasing college faculty instructional productivity, ASHE-ERIC. Higher Education Report, 4. Washington, DC: George Washington University.

[15] Johnson, D.W., Johnson, R.T., \& Smith, K.A. (1998). Cooperative Learning returns to college. Change, 30 (4):26-35.

[16] Kagan, S., (1990). Cooperative Learning resources for teachers. Published by: Resources for Teachers.

[17] Laird, T. (2005). Measuring deep approaches to learning using the National Survey of Student Engagement. Paper presented at the Annual Meeting of the Association for Institutional Research. Chicago, IL.

[18] Lave, J. (1988). Cognition in practice. Cambridge: Cambridge University Press.

[19] Liu, R., (1999). College English Teaching. Beijing: Foreign Language Teaching and Research Press.

[20] Li, X. (1984). In defence of the communicative approach. English Language Teaching Journal, 38, 2-13.

[21] Maley, A. (1984). On chalk and cheese, babies and bathwater and squared circles: Can traditional and communicative approaches be reconciled? In P. Larson, E. L. Judd, \& D. S. Messerschmitt (Eds.), On TESOL, 84 (pp. 159-169). Washington, DC: TESOL.

[22] McDonough, J. \& Shaw, C. (2003). Materials and Methods in ELT: a Teachers' Guide. Oxford: Blackwell Publishing.

[23] Mckay, H. \& A. Tom. (1999). Teaching Adult Second Language Learners. The United Kingdom: Cambridge University Press.

[24] Medgyes, P. (1986). Queries from a communicative teacher. ELT Journal, 40,107-112.

[25] Ministry of Education of the People's Republic of China. (2007). ELT Curriculum Requirements. Beijing: Foreign Language Teaching and Research Publishing House.

[26] Murray, F.B. (1994). Why Understanding the Theoretical Basis of Cooperative Learning Enhances Teaching Success. Baltimore: P. H. Brooke's Pub. Co.

[27] Nunan, D. \& Lamb, C. (1996). The self-directed teacher- managing the learning process. Cambridge: Cambridge University Press.

[28] Ovando, C. J., Combs, M. C.,\& Collier, V.P.(2006). Bilingual \& ESL classrooms: Teaching in multicultural contexts. New York: McGraw-Hill.

[29] Piaget, J. (1926). The language and thought of the child. New York: Harcourt Brace.

[30] Richards, J. C. \& Rodgers, T. S. (2003). Approaches and Methods in Language Teaching (Second edition). Cambridge: Cambridge University Press.

[31] Sampson, G. P. (1984). Exporting language teaching methods from Canada to China. TESL Canada Journal, 1(1), 19-32.

[32] Sarasin, L. C. (1999). Learning styles: Impact in the classroom. Madison, Wisc.: Atwood.

[33] Scovel, T. (1983). The impact of foreign experts, methodology and materials on English language study in China. Language Learning and Communication, 2(1), 83-91.

[34] Sharan, S. (1980). Cooperative Learning in small groups: Recent methods and effects on achievement, attitudes and ethnic relations. Review of Educational Research, 50(2), 241 - 271.

[35] Slavin, R.E. (1980). Cooperative Learning. Review of Educational Research, 50(2), 315 - 342.

[36] Slavin, R.E. \& Karweit, N. (1981). Cognitive and Effective Outcomes of an Intensive Student Team Learning Experience. Journal of Experimental Education, 50, 29-35.

[37] Spencer, L. (1986). An adjunct-model English-language program in Beijing. Monday Morning/Lundi Matin, 2(1), 7-9.

[38] Vygotsky, L.S. (1978). Mind in society. Cambridge, MA: Harvard University Press.

Weihong Li was born in Huhhot, Inner Mongolia, China in 1973. She received her MA degree in TESOL from Sunderland University, Britain in 2008. She is currently a lecturer in the Foreign Language Department, Beijing Information Science University, Beijing, China. Her academic research mainly focuses on applied linguistics and L2 socialization. 